\title{
Antisipasi Dampak negatif Penggunaan Smartphone Bagi Siswa kelas XI SMA Negeri 8 Batang Hari Melalui Layanan Bimbingan Kelompok
}

\author{
Iyut Mardiati \\ Sekolah Menengah Atas Negeri 8 Batang Hari
}

Abstract:Smartphones as a medium of communication bring convenience to humans anywhere in the world to communicate, helping humans to shorten the mileage. No need to meet physically, but in the air can exchange information and deliver messages. In particular Smartphone technology is increasingly making human privacy so awake. If it is controlled, the smartphone certainly has a positive impact. However, if not, the facilities in the Smartphone can be misused.

Keywords: Anticipation, Negative impact, Smartphone usage

\section{Pendahuluan}

Kemajuan teknologi adalah hal yang patut disyukuri. Sebab dengan sentuhan teknologi berbagai pemenuhan kebutuhan hidup manusia menjadi lebih mudah. Pada dasarnya, teknologi membawa implikasi positif dalam sejarah kehidupan manusia. Bahkan, kemajuan teknologi menjadi bukti perkembangan kemampuan manusia untuk menggunakan nalar dan pikirannya dalam mengelola alam dan potensi diri manusia itu sendiri.

Akan tetapi, jika pemanfaatan teknologi kemudian disalahgunakan, maka yang muncul adalah beragam dampak buruk. Tidak hanya tujuan utama dari perkembangan ilmu pengetahuan dan teknologi yang tidak tercapai, namun penyalahgunaan rekayasa teknologi itu sendiri akan membuat hidup manusia semakin sulit. Tidak terkendali. Menjadi linglung bahkan menjadi ambigu. 
Perkembangan teknologi komunikasi dan informasi melalui Smartphone ternyata telah membawa kemudahan bagi manusia dibelahan manapun di dunia ini untuk berkomunikasi. Hal ini sangat menolong manusia untuk memperpendek jarak tempuh. Tidak perlu bertemu secara fisik, namun diudara bisa saling bertukar informasi dan menyampaikan pesan. Secara khusus teknologi Smartphone semakin membuat privasi manusia begitu terjaga. Jika dikendalikan, Smartphone tentu membawa dampak positif. Akan tetapi jika tidak, fasilitas dalam Smartphone bisa saja disalahgunakan.

Hal itulah yang kita saksikan terjadi bagi kalangan pelajar. Sebagaimana diungkapkan sejumlah media massa banyak pelajar yang sudah menggunakan Smartphone berikut dengan fasilitas dan fitur yang ada didalamnya untuk hal-hal yang tidak sewajarny dan mengakses hal-hal yang berbau pornografi dan pergaulan bebas. Hal ini dapat memicu terjadinya hal-hal negatif yang tidak kita inginkan seperti pergaulan bebas dikalangan para Pelajar.

Dari gambaran diatas tercermin bahwa dampak negatif aktifitas penggunaan Smartphone di kalangan siswa lebih mendominasi siswa secara umum,dan salah satu upaya yang dinilai cukup efektif untuk mengatasi hal tersebut adalah melalui pendekatan bimbingan kelompok, oleh karena itu penulis memilih judul "Antisipasi Dampak Negatif Penggunaan Smartphone bagi Siswa Kelas XI SMA Negeri 8 Batang Hari melalui Layanan Bimbingan Kelompok".

\section{Landasan Teori}

\section{Pengertian Remaja dan perkembangannya}

Masa remaja sering dikaitkan dengan mulai adanya perkembangan yang mengarah pada fungsi organ vital secara 
keseluruhan. Menurut para ahli psikologi usia remaja sangat bervariasi tergantung tingkat perkembangan remaja itu sendiri, dan dimulai dari usia 13 tahun sampai 17 tahun, bahkan ada juga ahli yang memperkirakan masa remaja sekitar usia 14 tahun sampai sebelum dia menikah. Menurut Konopka dalam psikologi perkembangan remaja (Agus 2009, p.58), masa remaja meliputi : (a) masa remaja awal: 12-15 tahun, (b) remaja madya: 15-18 tahun, (c) remaja akhir: 19-22 tahun. Sementara Salzman mengemukakan, bahwa remaja merupakan masa perkembangan sikap tergantung (dependence) terhadap orang tua kearah kemandirian (independence), minat-minat seksual, perenungan diri dan perhatian terhadap nilai-nilai estetika dan perenungan moral. Masa remaja dipandang sebagai masa yang unik karena merupakan masa yang sukar, masa yang bergelora, masa tak menentu, masa sturm und drung dan penuh dengan tantangan atau dapat disimpulkan dengan masa ujian. Masa sukar dimengerti yang harus difahami, masa bergelora yang harus diselami. Baik oleh remaja itu sendiri maupun oleh siapa saja yang berkepentingan di dalamnya. (Agus, 2009, p.60)

\section{Tugas-tugas Perkembangan Remaja}

Robert Havirgust (Adam \& Gullota, 1983, p.87) Melalui perspektif psikososial (Yusuf 2007, p.200) berpendapat bahwa periode yang beragam dalam kehidupan individu menuntut untuk menuntaskan tugas-tugas perkembangan yang khusus. Tugas-tugas ini berkaitan erat dengan perubahan kematangan, persekolahan, pekerjaan, pendalaman beragama,dan hal lainnya sebagai prsyarat untuk pemenuhan dan kebahagiaan hidupnya, dan tugas perkembangan itu merupakan suatu tugas yang muncul pada periode tertentu dalam rentang kehidupan individu, yang apabila tugas itu dapat berhasil dituntaskan akan 
Iyut Mardiati

membawa kebahagiaan dan kesuksesan dalam menuntaskan tugas perkembangan berikutnya, sementara apabila gagal, maka akan menyebabkan ketidakbahagiaan pada diri yang bersangkutan, menimbulkan penolakan masyarakat, dan kesulitan-kesulitan dalam menuntaskan tugas-tugas berikutnya.

\section{Fungsi Smartphone Bagi Pelajar}

Handphone yang dalam perkembangannya sudah semakin canggih dan multifungsi sudah bukan lagi barang eksklusif. Saat ini, nyaris setiap orang memilikinya. Tentu fungsi primernya masih tetap sama : alat komunikasi. Meski demikian, selain fungsi teknis sebagai alat komunikasi, ternyata fungsi sosial atau katakanlah fungsi sekunder justru lebih mendominasi dan memotivasi individu untuk memilikinya, perkembangan media sosial yang semakin memberikan peluang dan ragam kebutuhan sebagi media publikasi dan informasi serta akses yang sangat cepat berkembang dan menawarkan fitur-fitur baru yang menawarkan berbagai aplikasi dan kecanggihan yang membuat dunia seolah-olah menjadi sempit, jarak begitu dekat dan perguliran waktu 24 jam sehari terasa begitu singkat dan mampu menghipnotis semua kalangan untuk menjadikan smartphone sebagai kebutuhan mutlak yang mesti dimiliki dan digunakan pada aktivitas dan kegiatan sehari-hari.

\section{Dampak Handphone Bagi Pelajar}
Dampak Positif
1. Sebagai alat komunikasi dan informasi
2. Menambah pengetahuan tentang perkembangan teknologi
3. Memperluas pergaulan secara sosial 


\section{Dampak Negatif}

1. Mengganggu Perkembangan Anak.

Dengan canggihnya fitur - fitur yang tersedia di Smartphone seperti kamera, permainan (games), media sosial yang beragam (facebook, line, twitter, whatsapp, bbm dll) akan mengganggu siswa dalam menerima pelajaran disekolah. Tidak jarang mereka disibukkan dengan mengotak atik dan update status ketika jam pelajaran disekolah secara diam-diam. Bahkan ada juga siswa yang menggunakan Smartphone untuk mencontek (curang) dalam ulangan. Bermain games saat guru menjelaskan pelajaran dan sebagainya. Kalau hal tersebut dibiarkan, maka generasi yang kita harapkan akan menjadi budaj teknologi.

\section{Efek Radiasi}

Selain berbagai kontroversi diseputar dampak negatif penggunaanya. Penggunaan Smartphone juga berakibat buruk terhadap kesehatan, ada baiknya siswa lebih berhati - hati dan bijaksana dalam menggunakan atau memilih Smartphone, khususnya bagi pelajar anak - anak. Jika memang tidak terlalu diperlukan, sebaiknya anak - anak jangan dulu diberi kesempatan menggunakan Handphone secara permanen.

3. Rawan Terhadap Tindak Kejahatan

Ingat, pelajar merupakan salah satu target utama dari pada penjahat.

4. Sangat Berpotensi Mempengaruhi Sikap dan Perilaku Siswa 
Jika tidak ada kontrol dari guru dan orang tua. Smartphone bisa digunakan untuk menyebarkan gambar - gambar yang mengandung unsur porno dan sebagainya yang sama sekali tidak layak dilihat seorang pelajar.

\section{Pengertian Bimbingan dan konseling Kelompok}

Terbentuknya berbagai kelompok dalam kehidupan manusia merupakan wujud dari hakikat kemanusiaan, khususnya dari dimensi kesosialannya. Manusia adalah mahluk sosial, yang tak mungkin dapat hidup berkembang secara layak apabila ia hidup sendiri dan menyendiri. Oleh karena itu, manusia selalu berusaha hidup dalam kumpulannya dan dalam kebersamaannya serta membentuk kelompokkelompok.

\section{Tahapan Bimbingan Kelompok serta Peranan Konselor dan siswa (klien) dalam Kegiatan Bimbingan dan Konseling Kelompok}

Bagi Guru pembimbing atau konselor di sekolah, pelaksanaan kegiatan bimbingan kelompok dan konseling kelompok mengikuti lima urutan kegiatan, yaitu: (1) Perencanaan, (2) Pelaksanaan, (3) evaluasi, (4) analisis hasil evalusi, dan (5) tindak lanjut. Perencanaan kegiatan layanan meliputi penetapan:

1. Materi layanan

2. Tujuan yang ingin dicapai, yaitu tujuan bimbingan kelompok dan konseling kelompok

3. Sasaran kegiatan, yaitu kelompok yang dimaksudkan

4. Bahan atau sumber bahan untuk kelompok tugas, mungkin ada bahan-bahan tertentu yang perlu dipersiapkan oleh Guru pembimbing

5. Rencana penilaian 
6. Waktu dan tempat

\section{Pendekatan Bimbingan Kelompok Sebagai upaya Antisipasi} dampak negatif penggunaan Smartphone bagi Siswa

Pendekatan bimbingan kelompok sebagai salah satu layanan dalam pelayanan Bimbingan dan Konseling disekolah diharapkan mampu menjadi jembatan keterbukaan berfikir siswa dalam mengantsipipasi dampak negatif penggunaan smartphone dikalangan pelajar seiring dengan perkembangan siswa sebagai suatu kepribadian, selain itu dinamika kelompok juga diharapkan juga dapat menjadi suatu wadah bagi siswa untuk menuntaskan berbagai permasalahan yang dihadapi oleh siswa.

\section{Metodologi Penelitian}

Subyek (populasi) yang menjadi responden pengembangan Model Pelayanan Bimbingan dan konseling adalah seluruh siswa kelas XI yang berjumlah 85 orang siswa yang terbagi dalam 4 kelas yakni kelas XI IPA1 berjumlah 21 orang siswa, XI IPA 2 berjumlah 21 orang siswa XI IPS 1 berjumlah 22 orang siswa, dan XI IPS 2 berjumlah 21 orang siswa.

\section{Tabel 1. Data Jumlah Siswa Kelas XI SMAN 8 Batang Hari}

\begin{tabular}{|c|c|c|c|}
\hline \multirow{2}{*}{ Kelas } & \multicolumn{2}{|c|}{ Jumlah Siswa } & \multirow{2}{*}{ Jumlah } \\
\cline { 2 - 3 } & Putra & Putri & \\
\hline XI IPA 1 & 7 & 14 & 21 \\
XI IPA 2 & 6 & 15 & 21 \\
XI IPS 1 & 9 & 13 & 22 \\
XI IPS 2 & 11 & 10 & 21 \\
\hline
\end{tabular}




\begin{tabular}{|l|l|l|l|}
\hline Jumlah & 33 Orang & 52 Orang & 85 Orang \\
\hline
\end{tabular}

\section{Hasil}

Studi Evaluatif Kondisi lapangan, Kajian Teoritik dan Ketentuan Formal.

Berdasarkan data dan informasi yang dikumpulkan bahwa, 70 dari 85 atau 82,35\% orang siswa kelas XI memiliki Smartphone.

Berdasarkan data diatas bahwa persentase siswa yang memiliki Smartphone cukup tinggi, dan dampak negatif Smartphone dapat saja menyerang seluruh siswa yang memiliki Smartphone, dan hal ini dapat terjadi diberbagai aspek, misalnya sikap dan perilaku siswa yang akan berpengaruh terhadap perkembangan kepribadian siswa itu sendiri, suasana dan aktivitas belajar siswa sebagai salah satu upaya untuk meraih cita-cita danmasa depan siswa, serta tingkat kreativitas dan produktivitas siswa sebagai generasi muda. Selain data tentang status siswa yang memiliki Smartphone berdasarkan himpunan data yang berasal dari legger nilai diperoleh data bahwa 40 siswa dari 85 atau $47,05 \%$ siswa yang memiliki Smarthone memiliki rata-rata hasil belajar sesuai KKM ( 77).

\section{Uji Coba Pelaksanaan Terbatas}

\section{Persiapan}

Pada tahap persiapan selain pengumpulan data dan informasi terhadap permasalahan yang akan dibahas dalam pengembangan model layanan bimbingan dan konseling yang dalam hal ini mengembangkan model pendekatan bimbingan kelompok sebagai upaya antisipasi dampak negatif penggunaan Smartphone Bagi siswa kelas XI SMA N 8 Batang Hari, maka para siswa ( klien ) yang akan berperan dalam 
dinamika kelompok perlu diberikan layanan informasi tentang kegiatan tersebut yang diawali dengan kegiatan bimbingan kelompok untuk membangun komitmen bersama, dan juga siswa diharapkan dapat memahami tahapan-tahapan bimbingan dan konseling kelompok sehingga siswa dapat berperan secara optimal didalam kelompok tersebut, sehingga tujuan yang diharapkan dapat tercapai melalui kebersamaan yang dibangun melalui dinamika kelompok.

Pelaksanaan

Pelaksanaam pengembangan model Layanan BK yakni pendekatan bimbingan kelompok dilaksanakan beberapa kali untuk mendekati hasil optimal yang diharapkan oleh Guru pembimbing sebagai perencana dan pelaksana kegiatan, dan siswa sebagai peserta didik yang diberikan layanan, pelaksanaan secara universal dilakukan beberapa kali, namun untuk pengkajian peneliti fokus pada beberapa kelompok yang memiliki permasalahan yang perlu diproritaskan untuk pemecahan masalah sebagai sampel pengembangan model pendekatan Bimbingan kelompok sebagai upaya antisipasi dampak negatif penggunaan Smartphone bagi siswa kelas XI SMA N 8 Batang hari.

\section{Penilaian}

Penilaian yang dilakukan pada kegiatan bimbingan kelompok yang dilaksanakan adalah Laiseg (Penilaian Segera) dan laijapen \& Laijapan (penilaian jangka panjang)

Penilaian segera (Laiseg):

- Mengakomodir respon siswa terhadap kegiatan bimbingan kelompok yang dilaksanakan. 
Iyut Mardiati

- tingkat antusias siswa dalam berperan serta menyelesaikan masalah melaui dinamika kelompok.

- Keterbukaan siswa dalam kelompok.

Penilaian jangka panjang (Laijapen dan laijapan):

- Pemantauan hasil belajar siswa (Laijapen)

- Pemantauan terhadap perubahan sikap dan perilaku siswa dan aspek perkembangan kepribadian siswa (Laijapang)

\section{Perbaikan Model Akhir Pelayanan Bimbingan dan Konseling di}

\section{Sekolah}

Kerangka konseptual dalam pengembangan model layanan bimbingan dan konseling,yakni: antisipasi dampak negatif penggunaan Smartphone bagi siswa kelas XI SMA N 8 Batang Hari Melalui Layanan bimbingan kelompok, mengacu pada prosedur pengembangan model layanan yang meliputi tahap I sampai dengan tahap VI maka kerangka berfikir dalam mengembangkan model layanan.

\section{Kesimpulan}

Berdasarkan hasi penelitian dan pengembangan model layanan bimbingan dan konseling yang telah dilaksanakan dapat disimpulkan bahwa:

1. Siswa sangat memerlukan keberadaan layanan bimbingan dan konseling disekolah serta peran serta nyata dari guru pembimbing untuk membimbing mereka dalam menyelesaikan tugas-tugas perkembangan yang harus mereka selesaikan.

2. Bimbingan dan konseling kelompok merupakan salah satu wadah bagi mereka untuk saling berbagi dalam pengentasan berbagai masalah melalui dinamika kelompok. 
3. Dinamika kelompok juga merupakan salah satu upaya untuk melatih kemandirian siswa dalam menetukan alternatif pemecahan masalah, melatih siswa untuk bersikap lebih terbuka terhadap lingkungannya, melaitih siswa untuk menumbuhkan kepercayaan terhadap diri dan orang lain.

4. Dinamika kelompok juga sebagai salah satu wahana bagi pengembangan kehidupan sosial siswa agar dapatberinteraksi dan mengembangkan kemampuan berkomunikasi secara efektif.

5. Pemanfaatan dinamika kelompok dalam pengamalan fungsi dan peranan bimbingan dan konseling disekolah diharapkan dapat mengantarkan siswa pada kesuksesan pencapaian tugas-tugas perkembangan remaja siswa SMA sangat memerlukan perhatian dan peranan besar orang-orang dewasa yang berada disekitar meraka untuk memberikan bimbingan dan arahan agar nereka tidak tersandung dampak negatif penggunaan Smartphone, sehingga melalui bimbingan kelompok yang mana mereka berada dalam suatu kelompok psikologis diharapkan memiliki tingkat efektifitas yang tinggi dalam pencegahan dan pengentasan masalah siswa, ini dapat terbukti dengan keterbukaan dan keantusiasan para siswa untuk mneyelesaikan dalam kelompok melalui kegiatan konseling kelompok yang telah dirancang dan dilaksanakan. 


\section{Daftar Rujukan}

Admin.(Anca,Postingan:Rabu-10/28/2015). Dampak Penggunaan Smartphone Bagi anak, Artikel. Online. Halaman tersedia : http ://www.kompasiana.com

Agoes Sujanto.2009.Psikologi Perkembangan,Edisi Revisi cetakan kesebelas Jakarta: Rineka Cipta

Agoes Sujanto,dkk.2008.Psikologi Kepribadian, Jakarata: Bumi Aksara

Arikunto,S. 2009. Prosedur Penelitian. Edisi revisi VI Jakarta: Rineka Cipta

Direktorat Jendral Pendidikan Tinggi. 2008. Dasar-Dasar Bimbingan dan Konseling. Depdikbud Proyek Pembinaan Mutu tenaga Kependidikan.

Direktorat Pembinaan Sekolah Menengah Atas. 2008, Pengembangan Perangkat Penilaian.DEPDIKNAS.

DEPDIKNAS.2008, Direktorat Jenderal Manajemen Pendidikan Dasar dan Menengah. Pedoman Pelaksanaan Pelayanan Konseling Pada Satuan Pendidikan dasar dan Menengah. PPPPTK Penjas dan BK. Ditjen PMPTK.

Prayitno.2008. Layanan Bimbingan dan Konseling Kelompok (Dasar dan Profi) Jakarta : Ghalia Indonesia

Prayitno,dkk, 2006. Seri Pemandu Pelaksanaan Bimbingan dan Konseling di SLTA, Panebar Aksara

Prayitno,dkk, 2010. Seri Kegiatan Pendukung Konseling.Jurusan Bimbingan dan Konseling. Fakultas Keguruan dan Ilmu Pendidikan.UNP

Prayitno,dkk, 2010. Seri Layanan Konseling.Jurusan Bimbingan dan Konseling. Fakultas Keguruan dan Ilmu Pendidikan.UNP

Sarwono, sarlito wirawan.2002 Psikologi Sosial, Jakarta: PT Rajagrafindo Persada

Sumadi Suryabrata. 2012. Psikologi Pendidikan, Jakarta: PT Rajagrafindo Persada

Sukardi,Dewa Ketut.2010. Pendekatan Konseling Karir didalam Bimbingan Karir.Jakarta: Ghalia Indonesia

Syamsu Yusuf \& Djawad Dahlan. 2007. Psikologi Perkembangan anak dan remaja, Bandung: PT Remaja Rosdakarya

Syamsu Yusuf \& juntika Nurihsan. 2008. Landasan Bimbingan dan Konseling, Bandung: PT Remaja Rosdakarya 